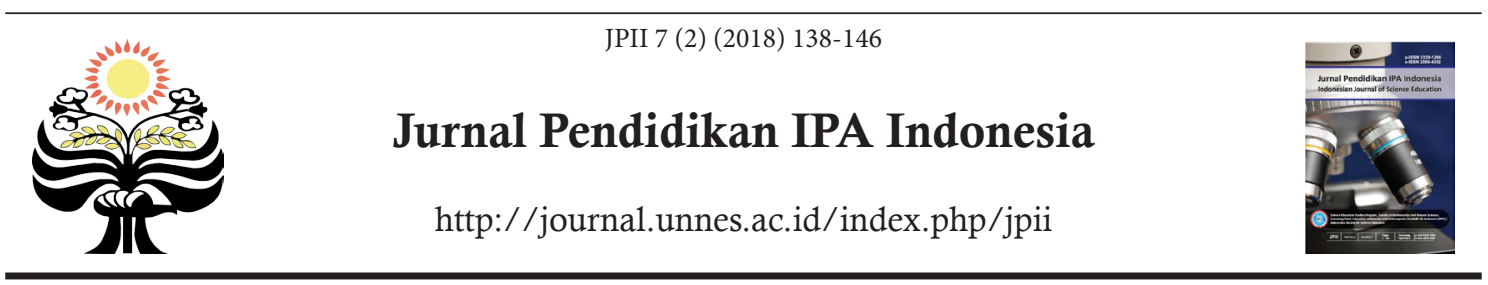

\title{
STUDYING NATURAL SCIENCE IN ELEMENTARY SCHOOL USING NOS-ORIENTED COOPERATIVE LEARNING MODEL WITH THE NHT TYPE
}

\author{
I. N. Jampel ${ }^{*}$, Fahrurrozi ${ }^{2}$, G. Artawan ${ }^{3}$, I. W. Widiana ${ }^{4}$, \\ D. P. Parmiti ${ }^{5}$, J. Hellman ${ }^{6}$ \\ 1,3,4,5 Universitas Pendidikan Ganesha, Bali, Indonesia \\ ${ }^{2}$ Jakarta State University, Indonesia \\ ${ }^{6}$ University of Gothenburg, Sweden
}

DOI: $10.15294 /$ jpii.v7i2.9863

Accepted: February $3^{\text {rd }}, 2018$. Approved: May $7^{\text {th }}, 2018$. Published: June $30^{\text {th }}, 2018$

\begin{abstract}
Elementary school students' achievement in natural science in the academic year of 2015/2016 at Cluster V, Buleleng regency, Bali province was considerably low. An early observation also revealed low motivation, negative attitudes towards teachers, low self-esteem and low confidence in self-capability. Therefore, a breakthrough approach was urgently required to improve the students' performance in natural science learning. The current article aimed at investigating the effects of the (Nature of Science) NOS-oriented cooperative learning model with the Numbered Head Together (NHT) on the elementary school students' achievement in natural science. The study was a quasi-experimental research adopting the post-test only control group design. The research conducted in elementary schools in Cluster V Buleleng sub-district, Buleleng regency, Bali, Indonesia. The research subject was 137 students in Grade 5 consisting of six classes from 5 elementary schools. The hypothesis was examined using an inferential statistics, the t-test. The results showed that there was a significant difference in the learning results of natural science between the students taught with the NOS-oriented cooperative learning model with the NHT type and those with the conventional learning model ( $\mathrm{t}$ count $=7,048>\mathrm{t}$ table $=2,000$ ). The students taught with the NOS-oriented constructive learning model with the NHT type achieved better than those with the conventional learning model. Therefore, it concluded that the NOS-oriented cooperative learning model with the NHT type gave positive effects on the fifth year students' achievement in natural science learning.
\end{abstract}

(C) 2018 Science Education Study Program FMIPA UNNES Semarang

Keywords: cooperative learning, elementary student, NHT

\section{INTRODUCTION}

The learning process implements in an interactive, inspirational, pleasing, challenging, and motivating style that facilitates students to take parts in the process actively and to give enough opportunities for the students' initiative, creativity, and autonomy in line with their talents, interests and their physical and psychological development. This activity systemically conducted

*Correspondence Address

E-mail: nyoman.jampel@gmail.com through the process of exploration, elaboration, and confirmation. This regulation is in line with the constructivism in which an individual is viewed to construct knowledge sustainably in assimilating and accommodating new information (Slavin, 1994). The basis of constructivism theory is that teachers' participation does not merely provide students with knowledge but also plays roles in developing students' ability, so that the students may be able to construct their own knowledge. Learning is not a stimulus-response paradigm but a process that needs one's self-di- 
rection and the formation of knowledge structure through reflection and abstraction.

The observation results conducted in 2015 in elementary school Cluster V Buleleng subdistrict showed that the learning activities in natural science were lack of innovations. Firstly, the learning activities were teacher-centered resulting in passive students. The teachers merely transferred knowledge to the students, and they received it without any direct discovery. Such classroom activities encouraged students to only memorize information. Secondly, teachers tended to use lecturing methods serving in the students' verbal knowledge of natural science. Thirdly, the classroom learning activities emphasized the drills and the problem-solving skill stick only on the examples of problem-solving given by the teachers. This causes the students not to be able to discover the ways to solve problems independently. Fourth, the facilities and infrastructures supporting the learning activities such as props were not made use of maximally. Fifth, during the learning process, the teachers rarely presented concrete phenomena or media related to the studied materials. The students needed some concrete media but most materials and contents of presentation were book-oriented. This made the students unable to understand the materials well. Sixth, the learning activities oriented more to competitive learning style. Hence, this learning style could cause anxieties to the students and this condition may spoil their motivation and create a hostile situation in the classroom.

The above findings supported by Lie (2002) suggesting that high achievers are often hated by their classmates since they are considered to increase the average grades and to bring their classmates down. Whereas, low achievers may cause some antipathy to classmates, teachers, school or even to the learning process. The label as losers in this competition may become a stigma or an inner wound that may always bother them in their lives. Widiana \& Jampel (2016) state that there are many elementary school teachers in Bali whose learning processes are monotonous like those described above and this causes their students' achievement to be low at the end. This learning process also applied for all subjects in elementary schools since the elementary school education in Indonesia adopts the home-room teacher system namely one teacher should handle 1 class in the learning process on the whole day for one year.

The teachers in elementary school cluster $\mathrm{V}$, Buleleng sub-district have an opinion that the learning package is seen from the basis of maste- ry learning without paying any attention to the learning process. It is in contradiction with the constructivism suggesting that students at all levels of ages actively involved in the process of gaining information and construct their own knowledge. As a result, the students' achievements are low. Based on the results of observations and document recording of grade 4 at the even semester in the academic year of $2015 / 2016$, in which the concerned students were still in Grade 5 in the odd semester in the academic year of $2016 / 2017$, found that the learning achievement of 5 Grade students in Cluster V Buleleng subdistrict was under low category. It shows their average scores of the semester exam for natural science which was under the Minimal Mastery Criteria of 65 (see Table 1). Natural science subject is one of the subjects in elementary schools studying a theoretical science based on the observations and experiments of the natural symptoms (Rahmawati, 2014).

Table 1. The Average Scores of the Semester Exam II for Natural Science of Students in Grade IV, Cluster V, Buleleng, Academic Year of 2015/2016.

\begin{tabular}{lcc}
\hline School Name & $\begin{array}{c}\text { Average } \\
\text { Score }\end{array}$ & $\begin{array}{c}\text { Score of } \\
\text { Minimal } \\
\text { Mastery } \\
\text { Criteria }\end{array}$ \\
\hline ES No.1 Petandakan & 60 & 75 \\
ES No.2 Petandakan & 58 & 75 \\
ES No.1 Sari Mekar & 61 & 75 \\
ES No.2 Sari Mekar & 62 & 75 \\
ES No. 1 Nagasepaha & 60 & 75 \\
\hline
\end{tabular}

The results of interviews with teachers and students revealed that the low quality of students' achievement in natural science was caused by some personality factors that did not support the learning activities such as low motivation, negative attitudes towards teachers, low self-esteem and low confidence in self-capability. Moreover, problems appearing during the learning process also caused students not to be enthusiastic and this was getting worse by the fact that most students did not concentrate on their learning process. It is in line with the results of observations that during the teaching and learning process in the natural science subject, the ways teachers presented the materials of natural science were less interesting. In the teaching-learning process, the teachers seemed to play active roles in presenting materials dealing with the concepts studied by students. The students tended to be passive and 
do less thinking processes. It is parallel with the research by Tirtasari, et al. (2015) suggesting that students' low achievement was caused by teachers' less innovative ways in packaging the learning process as clearly seen from the students' achievement in natural science.

On the basis of the condition, it is necessary to make some innovations in the natural science learning process in elementary school. The learning process of natural science should be based on the constructivist paradigm, a view on the learning activities that help students internalize, reform, or transform new information. In constructivist learning, it is the students who should be responsible for what they are learning, for becoming autonomous thinkers, developing integrated concepts, asking challenging questions, and for discovering their answers independently (Windschitl et al., 2008; Cobern, 2012). Some research also has revealed that constructivist-based learning may improve the students' learning process and achievement (Zaenuri et al., 2017).

To solve the weaknesses of such competitive and teacher-centered learnings as found in Cluster V Buleleng sub-district, Slavin (1994) suggests a learning setting with collaborative aspect namely cooperative learning model. It is parallel with the characteristic of the learning of natural science at school: the learning aims to help students study the main concepts and principles and apply them to solve any problems through various experiments/practices (Logman et al., 2012; Liu et al.,2009). The cooperative learning model is practical techniques that may be applied by teachers in their classrooms every day to help students study each subject, from basic skills to solve complex problems (Agustin et al. (2013). In the cooperative learning method, students work together in groups of $4-6$ to attain the understanding of the materials the teacher gave. Therefore, this cooperative learning model requires students to learn in mutual cooperation to solve problems, since this would promote interactions among students and help them foster a social relationship with their partners (Efriza \& Mukhaiyar, 2013).

According to Slavin (1994), the strength of the cooperative learning takes place in the opportunities obtained by students to discuss a problem, determine the strategies in solving it, and relate the problem with others that have already been solved. Learning in a cooperative group may train students to listen to others' ideas and to summarize the ideas or findings in the form of writing. Moreover, cooperative learning may also help students improve their positive attitudes towards natural science subject. Therefore, this may reduce or even omit any anxieties about the natural science subject that has much been experienced by students.

One of the effective cooperative learning models to improve the quality and achievement of natural science due to some problems above is the Numbered Head Together (NHT) type. NHT is a type of the cooperative learning models developed by (Kagan, 1994) to involve more students in studying the materials covered in a subject and to check their comprehension of the contents (Kusumaningtyas \& Kusmayadi (2014). Moreover, NHT is a cooperative learning type designed to influence the pattern of the students' interactions as an alternative for a traditional class structure. It is a structured working system/ study group in which positive interdependence, individual responsibility, personal interactions, expertise in cooperation and group process occur when students spend most of their time in the classroom in groups of 4-5 and accept recognition and rewards based on their groups' academic performances.

Novita (2008) explained the general steps in the model, which are (1) Numbering. Teachers divide students into some groups or teams consisting of 3-5 and give them numbers so that each student in the group has a different number. (2) Questioning. Teachers ask a question to students. The question may be various, from specific to general. (3) Head Together. Students think together to describe and to assure that each student knows the answer. (4) Answering. Teachers mention one number and students in each group with the same number raise his/her hand and are ready to answer for the whole class.

By studying the steps of NHT model in Cluster V Buleleng sub-district, it can be synthesized that the learning activities in the region were student-centered. Some findings underlying this was; first, the teachers did not use the lecturing method; second, the students were actively involved in the learning process; third, the students were asked to actively involved in discovering their own knowledge; fourth, the learning process made use of learning media either hand-made or those provided in the lab to make the learning process more interesting, and fifth, the learning became more collaborative in nature so that scientific sharing would happen during the learning process. Therefore, the elementary students' low achievement in natural science in Cluster V Buleleng sub-district may be improved.

This is reinforced by Zaenuri et al. (2017) stating that there are some improvements in the students' achievement in natural science when 
the cooperative learning model of NHT applied to the students Grade IV, semester I of the elementary school in Selat, Sukasada sub-district, Buleleng regency in the academic year of 201/2016. The average score of the achievement in the Cycle I was $66.75 \%$ which was under the 'moderate' category. Then, in the Cycle II, the average scores increased to $88.25 \%$ which was under the 'high' category in terms of the achievement level. Sastrawan, et al. (2014) also found out that there is a positive effect of the NHT type aided with learning media software on the achievement in natural science among the students in Grade 5 in Cluster III Busungbiu sub-district. The average score of the students' achievement in natural science taught using the cooperative learning model with the NHT type aided with learning media software was higher than those taught using conventional learning model.

It is believed that basic inquiries should be applied to teach natural science in elementary school instead of concept memorization. Therefore, in this research, the NHT type is oriented into the concepts of NOS. NOS-oriented learning is defined as "the nature of knowledge", which is a complex concept involving the philosophy, sociology, and history of a knowledge. The advantages of inserting the NOS to the standard/curriculum are improving the achievement of science materials, promoting the interest in science, and developing the decision making to any problems dealing with science (Widowati, et al, 2017). Santyasa (2007) suggested that NOS covers three things: ontology, epistemology, and axiology which are the bridge for the students in revealing and understanding the reality of nature that is really needed by students to understand their own identity and raise their awareness to love the nature and its contents. NOS-oriented learning has six parts namely (1) background readings, (2) case study discussions, (3) inquiry lessons, (4) inquiry labs, (5) historical studies, (6) multiple assessments.

There are five arguments about the importance of understanding NOS: (1) utilitarian; understanding NOS is needed to recognize science and to manage technological objects and process in daily life; 2) democratic; understanding NOS is required to get any information used to make decisions on socio-scientific issues, 3) cultural; NOS ought to be understood to respect the values of science as part of contemporary cultures, 4) moral; NOS is understood to help develop some understanding about the norms in scientific community in realizing some moral commitment to general values in the society, 5) science learning; understanding NOS may facilitate the lear- ning of materials in the science subject (Khishfe, 2012).

The concept of NOS learning-oriented has some characteristics related to nature so that students may be able to understand the learning materials contextually. The characteristics of NOS, which are: (1) NOS is good to be explicitly taught to future teachers and students to dig out concepts of natural science; (2) NOS are good to be contextually taught. Students may develop their functional understanding about NOS when they are taught in the context of scientific inquiry so that the learning is student-centered; (3) NOS is good to be taught on the basis of experiences. Teaching natural science through inquiry helps students understand the nature of scientific efforts seriously, where it cannot be obtained with full meaning through other ways; 4) NOS is good to be regularly taught. Regular treatment of the NOS subject matter covers a wide situation that will inspire students with understanding as it is; (5) NOS is good to be systematically taught. Teachers should know what to teacher dealing with the topics and mention all arrangements of information about NOS to the students. Teaching any subjects carelessly will result in some gaps in students' achievement. (6) By merely helping teachers focus their attention on NOS as an important purpose in the learning process, they will be able to produce the learning of natural science more clearly (Donche \& Petegem, 2011).

From the research results about NOS, it is suggested that teaching aspects of NOS be explicitly made with either contexts or non-context, as clearly stated in the curriculum/standard, textbooks or in the learning process in the classroom. It was found that the application of the visual media-aided NOS Learning Model was able to the achievement of Students Grade 5, Semester I in the academic year of 2011/2012 in Elementary School No. 2 Rendang, Rendang sub-district, Karangasem regency. It may be seen from their average score of 57.5 in the Cycle I and it became 70.93 in the Cycle II. Moreover, Haydon, et al. (2010) found that there is a positive effect from the NOS-oriented learning model on the students' understanding of the concepts of natural science. The theory used as the base for this research is the constructivism view that gives an emphasis on the student-centered learning activity so that the students may be able to construct their knowledge based on their own experiences.

This research tried to test the effects of the NOS-oriented cooperative learning model with the NHT type on the elementary school students' achievement in natural science. Teach- 
ers are expected to make the research results as one of the references to make their activities in learning natural science in elementary school more interesting, challenging, motivating and pleasing. Moreover, the research results would be able to support the students' achievement based on the expected basic competence possessed by the students of Grade 5 in elementary school. It is also expected that these research results would contribute to the development of the learning process in the field of natural science that has been achieved dealing with the application of the NOSoriented cooperative learning model with the NHT type in elementary school.

\section{METHODS}

This article is written based on the results of quasi-experimental research adopting the post-test only control group design. The research was conducted in elementary schools in Cluster V Buleleng sub-district, Buleleng regency in the semester $I$ in the academic year of 2015/2016. The population was 137 students Grade V consisting of 6 classes from 5 elementary schools namely ES No. 1, 2 Petandakan, ES No. 1, 2 Sari Mekar, and ES No. 1 Nagasepaha in Cluster $\mathrm{V}$ Buleleng sub-district, Buleleng regency in the academic year of 2015/2016. Fifty-nine students divided into two classes were randomly taken.

The data were students' achievement in the natural science subject. The data were collected through multiple choice test type with 20 items that had been contently and empirically validated. In terms of the content validity, the test employed had met the elements of the basic competence with good sentences in line with the psychological development of the students Grade 5 of elementary school. The empirical validity, however, was analyzed from the internal consistency of the 20 test items, and all the test items after being tested are valid. From the analysis of the discriminating power of test items, 3 test items qualified as very good; 9 items as good, and 8 items as moderate. From the analysis of the test difficulty level, 13 test items are under the easy, 5 items under moderate, and 2 under difficult. The analysis of the test reliability found that the test was qualified as high (0.66). The data on students' achievement in natural science were collected from the students using the post-test design after the NOS-oriented cooperative learning model with the NHT type and the conventional learning method had been applied.

The research hypotheses were analyzed using the t-test. However, to give some descriptions of the distribution of the research data, a descriptive analysis was made using the ideal mean criteria and the ideal standard deviation as presented in Table 2 .

Table 2. The Ideal Mean Criteria and Standard Deviation

\begin{tabular}{|c|c|c|}
\hline Score Range & $\begin{array}{l}\text { Real Score } \\
\text { Range }\end{array}$ & Category \\
\hline $\begin{array}{l}\mathrm{Mi}+1,5 \mathrm{SDi} \leq \mathrm{X} \leq \mathrm{Mi} \\
+3,0 \mathrm{SDi}\end{array}$ & $14,95 \leq \mathrm{X} \leq 20$ & Very high \\
\hline $\begin{array}{l}\mathrm{Mi}+0,5 \mathrm{SDi} \leq \mathrm{X}<\mathrm{Mi} \\
+1,5 \mathrm{SDi}\end{array}$ & $\begin{array}{l}11,65 \leq X< \\
14,95\end{array}$ & High \\
\hline $\begin{array}{l}\mathrm{Mi}-0,5 \mathrm{SDi} \leq \mathrm{X}<\mathrm{Mi}+ \\
0,5 \mathrm{SDi}\end{array}$ & $\begin{array}{l}8,35 \leq X< \\
11,65\end{array}$ & Moderate \\
\hline $\begin{array}{l}\mathrm{Mi}-1,5 \mathrm{SDi} \leq \mathrm{X}<\mathrm{Mi}- \\
0,5 \mathrm{SDi}\end{array}$ & $5,05 \leq X<8,35$ & Low \\
\hline $\begin{array}{l}\mathrm{Mi}-3,0 \mathrm{SDi} \leq \mathrm{X}<\mathrm{Mi}- \\
\text { 1,5 SDi }\end{array}$ & $0,01 \leq X<5,05$ & Very low \\
\hline
\end{tabular}

(Koyan, 2012)

\section{RESULTS AND DISCUSSION}

This research found that the experimental group after being treated with the NOS-oriented cooperative learning model with the NHT type, $58.62 \%$ students got the scores under the high and very high categories, $37.93 \%$ students were under the moderate category, 6.90\% under the 'low' and 'very low' categories. However, the control group showed different scores, and after being treated with the conventional learning method, $55.17 \%$ students got scores under 'low' and 'very low' categories, and $44.83 \%$ students were under the moderate category, but $0.00 \%$ students got the scores under 'high' and 'very high' categories. Therefore, it is descriptively stated that the distribution of the data in this research shows that the data on the students' achievement in the experimental group tended to be under the moderate or higher category, while in the control group, it tended to be under the moderate or lower category. The detailed post-test results of 30 students in the experimental group and 29 students in the control group are presented in Table 3. 
Table 3. Post-test Results of the Students from the Experimental and Control Groups

\begin{tabular}{cccl}
\hline $\begin{array}{c}\text { Real Score } \\
\text { Range }\end{array}$ & $\begin{array}{c}\text { Experimen- } \\
\text { tal Group }\end{array}$ & $\begin{array}{c}\text { Control } \\
\text { Group }\end{array}$ & Category \\
\hline $14,95 \leq \mathrm{X} \leq 20$ & $3(10,34 \%)$ & $0(0,00 \%)$ & Very high \\
$11,65 \leq \mathrm{X}<$ & $14(48,28 \%)$ & $0(0,00 \%)$ & High \\
14,95 & & & \\
$8,35 \leq \mathrm{X}<$ & $11(37,93 \%)$ & 13 & Moderate \\
11,65 & & $(44,83 \%)$ & \\
$5,05 \leq \mathrm{X}<8,35$ & $2(6,90 \%)$ & $\begin{array}{l}12 \\
(41,38 \%)\end{array}$ & Low \\
& & $4(13,75 \%)$ & Very low \\
$0,01 \leq \mathrm{X}<5,05$ & $0(0,00 \%)$ & &
\end{tabular}

Based on five-scale criteria and in line with the results of the data analysis, it knows that the mean score of the students' achievement in natural science in the experimental group, namely the group treated using the NOS-oriented cooperative learning model of NHT was 11.7 (under the high category). Whereas, the mean score of the students' achievement in natural science treated with the conventional learning model was 8.07 (under the moderate category). It means that the mean score of the students' achievement in natural science in the experimental group was higher than that in the control group. The data on the mean and standard deviation of post-test results of two groups are presented in Table 4.

Table 4. The Mean and Standard Deviation of the Post-Test Results of the Experimental and Control Groups

\begin{tabular}{ccccc}
\hline $\begin{array}{c}\text { Vari- } \\
\text { able }\end{array}$ & \multicolumn{2}{c}{ Experimental Group } & \multicolumn{2}{c}{ Control Group } \\
\hline \multirow{2}{*}{ Post-test } & Mean & $\begin{array}{c}\text { Standard } \\
\text { Deviation }\end{array}$ & Mean & $\begin{array}{c}\text { Standard } \\
\text { Deviation }\end{array}$ \\
\cline { 2 - 5 } & 11,7 & 2,01 & 8,07 & 1,98 \\
\hline
\end{tabular}

Before testing the hypothesis with the independent t-test, testing the prerequisite was needed for the distribution of the research data was made. The test of analysis of prerequisite includes two aspects: (1) the normality test of the data distribution for the whole analysis units, and (2) the homogeneity test of the variance among groups.

The normality test of the data made to the whole analysis units namely the experimental and the control groups using the Kolmogorov-
Smirnov and Shapiro-Wilk analyses. The process of the analyses was supported by the program of the SPSS 16 for Windows. The data normality was determined by the significance of the results of the analysis. The data are said to be normally distributed if the number of the significance obtained is more than 0.05 of at the significance level of $5 \%$. The summary of the results of the normality test of the data in the experimental and the control groups are presented in Table 5.

Table 5. Summary of the Results of the Normality Test of the Data Distribution

\begin{tabular}{lllllll}
\hline Learning & \multicolumn{3}{c}{$\begin{array}{c}\text { Kolmogorov- } \\
\text { Smirnov }\end{array}$} & \multicolumn{3}{c}{ Shapiro-Wilk } \\
& $\begin{array}{l}\text { Statis- } \\
\text { tic }\end{array}$ & Df & Sig. & $\begin{array}{l}\text { Statis- } \\
\text { tic }\end{array}$ & df & Sig. \\
\hline $\begin{array}{l}\text { Experi- } \\
\text { mental }\end{array}$ & 0,119 & 30 & 0,200 & 0,957 & 30 & 0,254 \\
$\begin{array}{l}\text { Group } \\
\text { Control }\end{array}$ & 0,129 & 29 & 0,200 & 0,929 & 29 & 0,052 \\
Group & & & & & & \\
\hline
\end{tabular}

Based on Table 5, it explains that the significance level is higher than 0.05 for all the units of analyses conducted using either the KolmogorovSmirnov or Shapiro-Wilk. This shows that the data in the experimental group distributed normally. This also happens with the control group. Therefore, the significance levels for whole units of analysis using either the Kolmogorov-Smirnov or the Shapiro-Wilk are higher than 0.05 , showing that the data in the control group also normally distributed.

The homogeneity test of the variance made for the data of the achievement of natural science in the experimental and control groups. The number of each unit of analysis was 30 and 29 students, respectively. In testing homogeneity of the variance between the groups, the F-test was employed. The data said to be homogeneous if the $\mathrm{F}_{\text {count }}<\mathrm{F}_{\text {table }}$. The summary of the results of the homogeneity test of the variance is presented in Table 6.

Table 6. Summary of the Results of the Homogeneity Test of the Variance using the F-test

\begin{tabular}{lllllll}
\hline Sample & Mean & SD & $\begin{array}{l}\text { Vari- } \\
\text { ants }\end{array}$ & $\mathbf{F}_{\text {count }}$ & $\mathbf{F}_{\text {table }}$ & Conclusion \\
\hline $\begin{array}{l}\text { Experi- } \\
\text { mental } \\
\text { group }\end{array}$ & 11,7 & 2,01 & 4,04 & & & \\
$\begin{array}{l}\text { Con- } \\
\text { trol } \\
\text { group }\end{array}$ & 8,07 & 1,98 & 3,92 & & & \\
\hline
\end{tabular}


Based on Table 6, with the aid of the program of Microsoft Excel 2007 for Windows it is shown that $\mathrm{F}_{\text {count }}<\mathrm{F}_{\text {table, }}$ meaning that the variance between the groups of the students is homogenous.

The hypotheses tested in this research states that there were differences in the result in studying natural science between students taught using the NOS-oriented cooperative learning method of NHT type and those taught using the conventional learning model. To test the proposed hypothesis, the independent-t-test or uncorrelated t-test was employed. Table 6 shows that when the variance is homogenous and the number of the student in each the class is the same, in the uncorrelated t-test, the pooled variance is adopted. The summary of the results of the uncorrelated t-test is presented in Table 7.

Table 7. Summary of the Data of the Results of the Hypothesis Testing

\begin{tabular}{|c|c|c|c|c|c|c|}
\hline Group & $\begin{array}{l}\text { Vari- } \\
\text { ance }\end{array}$ & $\mathbf{N}$ & $\mathbf{d b}$ & $\mathbf{T}_{\text {count }}$ & $\mathbf{T}_{\text {table }}$ & Conclusion \\
\hline $\begin{array}{l}\text { Experi- } \\
\text { mental } \\
\text { group }\end{array}$ & 4,04 & 30 & & & & $\mathrm{~T}_{\text {count }}>\mathrm{t}_{\text {table }}$ \\
\hline $\begin{array}{l}\text { Control } \\
\text { group }\end{array}$ & 3,92 & 29 & 57 & 7,048 & 2,000 & $\begin{array}{l}\mathrm{Ha} \text { is ac- } \\
\text { cepted }\end{array}$ \\
\hline
\end{tabular}

According to the hypothesis proposed in the theoretical study of the hypothesis testing criteria, H0is unaccepted if the tcount $>\mathrm{t} \neg$ table and $\mathrm{H} 1$ is accepted with the significance level of $5 \%$. In this research, the condition was supported by the difference in the mean score obtained by the experimental group, namely 11.7, under the very high category, and the control group, namely 9.07 under the 'moderate' (very high) category, the alternative hypothesis is accepted. It is also shown by the summary of the data of the hypothesis testing results that the tcount $>\mathrm{t} \neg$ table, therefore $\mathrm{H} 0$ is unaccepted and $\mathrm{H} 1$ is accepted. Therefore, it is interpreted that there was a significant difference in the achievement between the group of students taught using the NOS-oriented cooperative learning model with the NHT type in the natural science subject and those taught using the conventional learning model in the students grade $\mathrm{V}$, in the odd semester in the academic year of 2012/2013 in elementary schools in Cluster V, Buleleng sub-district, Buleleng regency.

This research result shows that there is a difference in the result of studying the natural science subject between the group of students taught using the NOS-oriented cooperative learning model and that of those taught using the conventional learning model. The mean score of the achievement in the natural science subject taught using the NOS-oriented cooperative learning model with the NHT type is 11.7 which is higher than the mean score of those taught using the conventional learning model, namely 8.07. It means that the NOS-oriented cooperative learning model with the NHT type positively gave effects on the 5 graders' achievement on the natural science, in the odd semester, academic year of 2012/2013 in elementary schools in Cluster V, Buleleng sub-district, Buleleng regency.

This research result showed that in the group of students taught using the NOS-oriented cooperative learning model with the NHT type, $58.6 \%$ students got scores under the high and very high categories, $37.93 \%$ students under the moderate category, and $6.90 \%$ student under the low and very low categories. This variation shows that the students' achievement is not only influenced by some factors of the learning model presented by the teacher, but also by some assumed factors of the facilities and infrastructures, students' self-confidence, learning motivation, students' talents, students' economic condition, school climate and management as suggested by the results of interviews with the students. This result reinforces a theory stating that the factors influencing the students' achievement may be categorized into two types namely internal factors coming from the students themselves and the external ones, from out of the students.

This research result is also supported by Sudirgayasa, et al. (2014) who found that there are ten factors influencing students' achievement in the accounting subject, namely: motivation, senses, the relation between the teacher and the students, the parents' attention, school discipline, the relation among the students, the relation among the family's members, learning tools, peer groups, and the parents' tolerance. Widiana \& Jampel (2016) found that request and motivation also influence the students' achievement.

The application of the NOS-oriented cooperative learning model with the NHT type was in line with the characteristics of the elementary school students at the concrete operational stage. It may be seen from their enthusiasm to be able to see, do something, involve learning, and experience directly at anything studied. The students were really interested in any materials specially packaged by the teacher according to their daily lives, moreover, they were asked to play during the learning process. It is supported 
by Piaget suggesting that elementary school students are at the concrete operational stage (from 7 to 11 years old) in which the concept existing at the early age is an opaque concept, and then at present, it becomes more concrete. Elementary school students make use of the mental operation to solve actual problems. They are able to use their mental capability to solve concrete problems also state that at the concrete operational stage, students are able to show concrete operations, logical thinking, object classification and thinking about the relationships among types of objects. Students' life experiences contribute to sharpening concepts. At this stage, elementary school students are able to think, learn, remember, and communicate since their cognitive process is not egocentric but logic.

This research result still reinforces the constructivism theory to improve the students' achievement. The learning process of the students taught using the NOS-oriented cooperative learning model with the NHT type is more attractive, pleasing and motivating for the students to learn. The results of the interviews with some students showed that the students felt to have more chances to explore themselves in the learning process. These students' statement supports the von Glasersfeld's (1989) learning concept that learning is not a stimulus-response symptom but a process that needs self-direction and one's structural construction of knowledge through reflection and abstraction. Learning is a process of efforts one makes to get new behavioral changes as a whole as the results of their own experiences with their environment. It is in line with the characteristic of the NHT learning that students are more involved in studying materials covered in a subject and checking their comprehension of the content of the lesson.

Moreover, the students also felt that they become more productive and careful in learning natural science. They seemed to be enthusiastic during the learning process either at the practices or at the group discussion. The students became more responsible for the problems given to them, more active in answering questions, and made the process of sharing knowledge among members of the group and among the members from other groups into reality. NHT learning model indirectly trains the students to share information, listen to and speak carefully to others, so that they are productive in the learning process ( $\mathrm{Ka}$ gan, 1994).

This research result also confirms some research results made by among other that the cooperative learning model with the NHT type gave effects on the students' achievement in the natural science (Sastrawan et al., 2014). Another research result also shows that the cooperative learning model with the NHT types applied in the learning activities significantly influenced the attainment of the students' achievement as a whole (Haydon et al., 2010). Besides strengthening the research of the application of the cooperative learning model with the NHT type, this research result also supports the research results of the application of the NOS-based learning model. The NOS-based learning model may improve the learning quality and also the resulting achievement in the learning activities. The application of the NOS-based learning process give significant effects on the students' achievement (Sudirgayasa, et al., 2014).

\section{CONCLUSION}

This research discovers that the NOSoriented cooperative learning model with the $\mathrm{N}$ NHT type gave positive effects on the achievement in the natural science of the students Grade $\mathrm{V}$ in the odd semester, academic year of 2015/2016 in elementary schools in Cluster V Buleleng subdistrict, Buleleng Regency. The NOS-oriented cooperative learning model showed better results in the students' achievement than the conventional learning model in natural science. This research positively contributes to the development of science, especially in the learning of the natural science. Therefore, it is suggested that teachers teach the materials of natural science using the NOS-oriented cooperative learning model as one of the alternatives to learning natural science so that the learning process becomes more effective. This research may also be made as a reference for further researches with different materials or subject matters, different grades, and those with new variables as a new creativity.

\section{REFERENCES}

Agustin, S., Ariyanto, S., \& Sukmaantara, I. P. (2013). The Effect of Using Numbered Head Together Technique on The Eighth Grade Students'reading Comprehension Achievement at SMPN 2 Tanggul Jember. Pancaran Pendidikan, 2(3), 201-210.

Brooks, J. G. (1999). In search of understanding: The case for constructivist classrooms. ASCD.

Cobern, W. W. (2012). Contextual Constructivism: The Impact of Culture on The Learning and Teaching of Science. In The Practice of Constructivism in Science Education (pp. 67-86). Routledge. 
Donche, V., \& Van Petegem, P. (2011). Teacher educators' conceptions of learning to teach and related teaching strategies. Research Papers in Education, 26(2), 207-222.

Efriza, D., \& Radjab, D. (2013). The Effect of Using Numbered Heads Together and Reading Motivation on Students'reading Comprehension of Descriptive and Narrative Text of SMPN 7 Muaro Jambi. English Language Teaching (ELT), 1(3), 5-12.

Haydon, T., Maheady, L., \& Hunter, W. (2010). Effects of Numbered Heads Together on The Daily Quiz Scores and On-task Behavior of Students with Disabilities. Journal of Behavioral Education, 19(3), 222-238.

Kagan, S., \& Kagan, S. (1994). Cooperative Learning (Vol. 2). San Juan Capistrano, CA: Kagan Cooperative Learning.

Khishfe, R. (2012). Nature of Science and Decisionmaking. International Journal of Science Education, 34(1), 67-100.

Koyan, I Wayan. 2012. Statistik Pendidikan.Singaraja. Universitas Pendidikan Ganesha Press

Kusumaningtyas, Y. P., Kusmayadi, T. A., \& Riyadi, R. (2014). Eksperimentasi Model Pembelajaran Think Talk Write (TTW) Dan Numbered Head Together (NHT) terhadap Prestasi Belajar Matematika ditinjau dari Konsep Diri Belajar Matematika Siswa di SMP Negeri E-Kabupaten Blora. Jurnal Pembelajaran Matematika, 2(2), 7-14.

Lie, A. (2002). Cooperative Learning: Mempraktikkan Cooperative Learning di Ruang-ruang Kelas. Jakarta: Grasindo.

Liu, T. C., Peng, H., Wu, W. H., \& Ming-Sheng, L. (2009). The Effects of Mobile Natural-Science Learning based on The 5E Learning Cycle: A Case Study. Journal of Educational Technology \& Society, 12(4), 344.

Logman, P. S. W. M., Kaper, W. H., \& Ellermeijer, A. L. (2012). Motivating Students to Perform an Experiment in Technological Design Contexts. Physics Alive, 98.

Rahmawati, D. (2014, May). The Effectiveness of Using Cooperative Learning Type Number Heads Together (NHT) Improving Reading Comprehansion of the Students at SMP N 20
Tangerang. In International Conference on Education and Language (ICEL) (Vol. 1).

Sastrawan, W., Sedanayasa, G., \& Suwatra, I. I. W. (2014). Pengaruh Model Pembelajaran Kooperatif Tipe Numbered Heads Together (NHT) dengan Bantuan Media Software Pembelajaran terhadap Hasil Belajar IPA Siswa Kelas V SD Gugus III Desa Bengkel Kecamatan Busungbiu. MIMBAR PGSD Undiksha, 2(1), 18-24.

Slavin, R. E. (1994). Educational Psychology: Theory And Practice. Allyn and Bacon.

Sudirgayasa, I. G., Suastra, I. W., \& Ristiati, N. P. (2014). Pengaruh Model Pembelajaran Berbasis Nature Of Science (NOS) terhadap Kemampuan Aplikasi Konsep Biologi dan Pemahaman NOS Siswa dalam Pembelajaran Biologi di SMA Negeri 1 Marga. Jurnal Pendidikan IPA Indonesia, 4(1), 22-28.

Nurlela, E. S. F., \& Sujana, A. (2016). Penerapan Pendekatan Contextual Teaching and Learning untuk Meningkatkan Hasil Belajar Siswa pada Materi Energi Panas. Jurnal Pena Ilmiah, 1(1), 501-510.

Von Glasersfeld, E. (1989, January). Knowing without Metaphysics: Aspects of the Radical Constructivist Position.

Widiana, I. W., \& Jampel, I. N. (2016). Learning Model and Form of Assesment Toward The Inferensial Statistical Achievement by Controlling Numeric Thinking Skills. International Journal of Evaluation and Research in Education, 5(2), 135-147.

Widowati, A., Nurohman, S., \& Anjarsari, P. (2017). Developing Science Learning Material with Authentic Inquiry Learning Approach to Improve Problem Solving and Scientific Attitude. Jurnal Pendidikan IPA Indonesia, 6(1), 32-40.

Windschitl, M., Thompson, J., \& Braaten, M. (2008). Beyond the Scientific Method: Model-based Inquiry As A New Paradigm of Preference for School Science Investigations. Science education, 92(5), 941-967.

Zaenuri, Z., Sudarmin, S., Utomo, Y., \& Juul, E. (2017). Habituation Model of Implementing Environmental Education in Elementary School. Jurnal Pendidikan IPA Indonesia, 6(2), 206-212. 